\title{
Investigation of Stability in Internal Turning Using a Boring Bar with a Passive Constrained Layer Damping
}

\section{B. A. G. Yuvaraju}

PhD scholar

Department of Mechanical Engineering National Institute of Technology Rourkela - 769 008, Odisha India

\section{B. K. Nanda}

Professor

Department of Mechanical Engineering National Institute of Technology Rourkela - 769 008, Odisha India

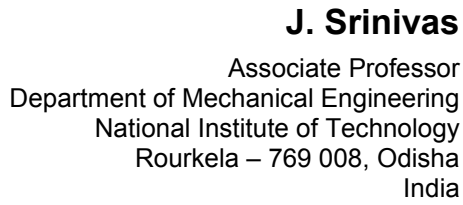

\section{INTRODUCTION}

Manufacturing industries, nowadays, produce various components despite the obstacles in obtaining more accurate products. Unwanted vibrations and noise generated during the machining often lead to frequent machine breakdowns, which results in imprecise products. Several researchers have focused on analysing and controlling the unwanted vibrations induced by different machining systems over the last two decades [1]. Internal turning or boring is one of the oldest machining processes for enlarging the cast holes or pre-drilled in a component. In this process, a highly accurate surface finish of the machined product is essential. Boring bar or tool is the weakest part of the internal process, and its motion depends on time. Accordingly, the deformation in the workpiece during internal turning, introduces vibration or dynamic motion in the boring tool. These vibrations worsen the quality of machined surface the surface finish, which results in the reduced tool life. The recent attention among researchers is to suppress the regenerative vibrations induced by the tool during machining. It is therefore necessary to minimise these

Received: March 2020, Accepted: January 2021

Correspondence to: B. A. G. Yuvaraju

Department of Mechanical Engineering, National

Institute of Technology, Rourkela-769 008, India.

E-mail: bagyuvaraju@gmail.com

doi: $10.5937 /$ fme2102384Y

(C) Faculty of Mechanical Engineering, Belgrade. All rights reserved vibrations by employing advanced control approaches.

Extensive research has been carried out to suppress regenerative chatter in machining by determining the optimal parameters such as the spindle speed, depth of cut, and feed rate [2, 3], spindle speed variation [4], and force control [5] techniques. On the other hand, various devices were designed for vibration suppression, such as passive, semi-active [6] and active control [7] devices. Many researchers paid attention to active dampers because of its efficiency and flexibility in vibration suppression. Various active vibration dampened boring bars designed with smart material and control technology used in research in recent times. The typical examples of active methods include boring bars with piezoelectric materials, magnetic actuators, electro-rheological fluid, and magneto-rheological fluid. Venter et al. [8], Yigit et al. [9] and Tang et al. [10] presented a novel method for vibration and chatter suppression in the boring bar by applying piezoelectric patches over its surface. They found that stability limits tripled for the optimum configuration shunt circuit components. Piezoelectric damping is an excellent alternative to improve the stability boundaries in turning or boring operations. Moreover, Mei et al. [11], Pour and Behbahani [12] and Biju and Shunmugam [13] used smart MR dampers on the boring bar for tuning the natural frequency of the tool which results reduced chatter and improved stability of machining system. 
The active control techniques are more adaptable to different cutting parameters and use various driving methods and control algorithms to reduce vibration. Active methods allow several modes to be damped simultaneously, but require actuators. Moreover, the control system's design is complicated, high consumption of external power and the actuators used are often massive. Large actuators present difficulties in the practical machining process, whereas the passive control devices are easy to design and implement and do not need external energy. Moreover, the structures of passive devices are simple. Dynamic vibration absorber (DVA), Lanchester damper and the impact damper are the most commonly used passive control devices. Fallah and Moetakef-Imani [14] developed a passively damped boring bar with tuned mass damper (TMD) using optimal design parameters and tested in a practical environment. The results showed the feasibility of the proposed method in industrial applications. Liu et al. $[15,16]$ have modelled boring bar with variable stiffness dynamic vibration absorber (VSDVA) based on dynamic vibration absorber theory and investigated its vibration characteristics both analytically and experimentally. They reported that the boring bar vibration could be efficiently suppressed by a tolerable axial compression selection. The vibration absorber techniques only damp several modes, effective over a narrow frequency band, and can degrade their performance because of forcing frequency changes.

Boring bar with impact damper to control the vibration of overhanging tool was first investigated by Thomas et al. [17], which was found to be the most effective and observed an increase in stable metal removal rates with improved designs. Later, Edhi and Hoshi [18] introduced an advanced type of impact damper called the friction damper to eliminate highfrequency chatter in fine boring, which was not controlled by impact dampers and found that the proposed damper was effective for boring tools which vibrate at a frequency of more than $5,000 \mathrm{~Hz}$. As the impact and friction dampers placed on the surface of the boring tool cause damage to the machined surface resulting in reduced surface roughness and tool life. Biju Shunmugam [19], Chockalingam et al.[20] and Diniz et al. [21] developed boring bar with particle impact dampers (PIDs), where particles placed inside the cavity of the tool for stability improvement by controlling the vibrations in internal turning. The momentum was transferred from the primary system to particles, and increased energy dissipation caused by the collision of the particles and cavity walls minimized the boring bar's vibrations. The PID boring bar makes it possible to increase the tool overhang without damaging surface roughness and tool life, and turn the longer holes than when a solid bar used. If the length to diameter (L/D) ratio of the boring bar considered is large, then it is difficult to implement a boring bar with a dynamic absorber to control vibration, which is limited by complications arrived during installation. Lee and Suh [22] and Nagano et al. [23] manufactured and tested a graphite-epoxy and a carbon fibre composite boring bars, respectively, to minimize chatter vibrations due to larger overhangs and stated that boring bars made up of two or more material increase the stiffness. Rivin and Kang [24] developed a boring tool with viscoelastic layers and observed improved stability, stiffness and damping. Further, Hwang and Kim [25] reported that boring bar made with two or more material increases the stiffness and results in reduced vibrations during the boring process. Suzuki et al. [26] and Ghorbani et al. [27] developed an anisotropic and a composite boring bar, respectively, to attenuate chatter and observed improved stability with the proposed boring tool compared to the standard cutting tool. Fu et al. [28] have used carbon-based nanocomposite coatings on boring bars to improve the dynamic stiffness and observed an improvement in the surface finish with the reduced vibration. Most of the control devices or methods proposed before were focused on suppression of the forced vibration, while the chatter suppression mechanism was not explained clearly because of its complication. Particularly in the low-velocity zones, stability lobes are uneven. Therefore, standard optimization method cannot be used in the high-velocity zones. Moreover, the use of simple viscoelastic composites results in lower damping capacity and lower stiffness than the particulate composite. To improve the stiffness and damping capacity, a constrained layer over a particulate composite boring bar need to be developed, which results in the reduced vibration displacements of the cutting tool.

Many researchers have studied the constrained layer damping (CLD) as the passive vibration control method, Ross et al. [29] the Constraint Layer Damper (CLD) for the suppression of structural vibrations. It was carried out by adhering to the structural component a viscoelastic layer protected by a stiff constrained layer. The dynamic characteristics of the structure have been improved by enhancing the dynamic stiffness and the damping ratio. The CLD was then widely used in many engineering applications. Gafrnis et al. [30] used a composite structure with honeycomb structure as a damping layer in the helicopter blade and analysed it through finite element analysis software. Rao et al. [31] and De et al. [32] adopted the CLD for eliminating the squeal noise of the disc brake in railway applications. Recently, a CLD boring bar designed and developed by Liu et al. [33] and Yuhuan et al. [34] has been validated to be used to control the vibration in boring experiments. However, they just optimized the CLD boring tool by the finite element method and preliminarily investigated its damping performance. Associated with $[33,34]$, the aim of this study is to propose a model using modal strain energy (MSE) for the CLD boring tool to design and optimize the damping parameters in finite element analysis, thereby improving the stability of the boring process. Moreover, limited work is noticed on the stability studies of boring operations with CLD boring bars.

Thus, in this work, the modelling procedure of the standard boring bar is initially presented using EulerBernoulli beam theory (EBT) and finite element modelling (FEM). The modal parameters are then evaluated from the impact hammer test to validate the results of EBT and FEM. Moreover, the stability lobe diagrams (SLDs) are constructed using these modal parameters to investigate the internal turning stability. A 
hybrid composite material such as carbon/SiC-epoxy is used as damping materials (sandwich material) over the tool surface, and modelling is further carried-out with equivalent material properties. The tool-tip responses are obtained from numerical simulations for both standard and CLD boring bar using EBT and FEM. Further, the numerical results are verified with real cutting experiments. The organization of the remaining part of this paper is given as follows. Section 2 presents the modelling of conventional and PCLD boring bars using beam theory and finite element analysis. Section 3 gives the experimental setup and procedure. The results and discussions are given in Section 4, and Section 5 concludes the paper.

\section{MODELLING OF THE BORING BAR}

The stiffness of the boring bar in axial (x) direction and torsion are much higher than in radial (y) and tangential (z) bending directions. Thus, the bending vibrations caused by radial and tangential forces are considered. However, the dynamic displacement in tangential direction doesn't affect the regenerative nature of the chip. In contrast, the dynamic displacement in radial direction varies with depth of cut and produce the regenerative effect. Therefore, a single degree-offreedom model shown in Figure 1 is considered because of the vibrations in radial cutting direction of the boring bar are most significant in internal turning [35].

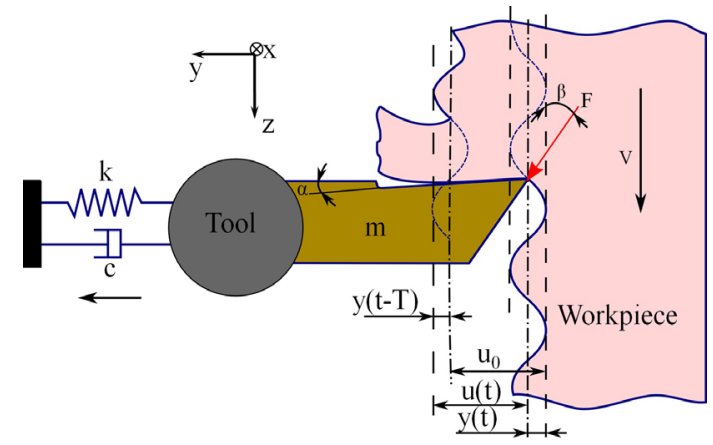

Figure 1. A single degree model representing boring operation. [35]

Further, the dynamic modelling of the conventional as well as CLD (that is passively damped constrained layered) boring bar are elaborated below using EulerBernoulli beam theory and finite element modelling.

\subsection{Euler-Bernoulli beam theory}

The cantilevered boring bar with Euler-Bernoulli beam element is presented in Figure 2. The governing equation to describe the dynamics of the boring bar is given by Sadredine et al. [36] as

$$
\rho A \frac{\partial^{2} y(x, t)}{\partial t^{2}}+c \frac{\partial y(x, t)}{\partial t}+E I \frac{\partial^{4} y(x, t)}{\partial x^{4}}=f(x, t)
$$

where, $E, A, c$, and $\rho$ are modulus of elasticity, crosssectional area, damping coefficient and density of the boring bar, respectively. $y(x, t)$ represents radial deflection of the boring bar and the distributed force acting on at the tip of the boring tool is expressed as $f(x, t)=K_{c} d[y(x, t)-y(x, t-T)]$.

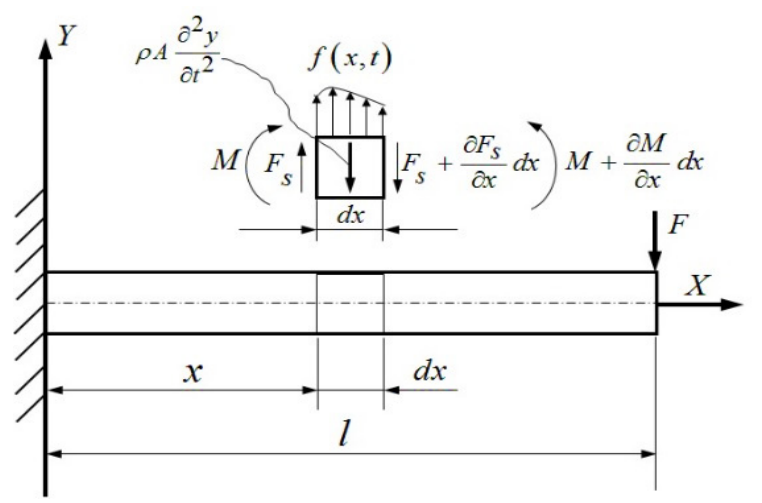

Figure 2. The dynamic model of the boring bar with EulerBernoulli beam element [37]

The mode superposition principle is used to solve (1), where the deflection of the beam is assumed as

$$
y(x, t)=\sum_{i=1}^{\infty} \chi_{i}(x) q_{i}(t)
$$

where, $\chi_{i}(x)$ and $q_{i}(t)$ denote the characteristic function and generalized coordinates, respectively. The boundary conditions at the fixed and free end are given as $\chi\left(x_{0}\right)=0, \chi^{\prime}\left(x_{0}\right)=0$ and $\chi^{\prime \prime}\left(x_{0}\right)=0, \chi^{\prime \prime \prime}\left(x_{0}\right)=0$, respectively. On substituting (2) in (1), the resultant equation is multiplied with $\eta_{i}(x)$ and integrated over the limits 0 to 1 , and applied the orthogonality conditions given in (3) and (4) the governing is further reduced.

$$
\begin{aligned}
& \int_{0}^{l} \rho \chi_{i}(x) \chi_{j}(x) d x=\delta_{i j} \\
& \int_{0}^{l} E I \chi_{i}^{\prime \prime}(x) \chi_{j}^{\prime \prime}(x) d x=\omega_{n i}^{2} \delta_{i j}
\end{aligned}
$$

The governing equation given in (1) is further modified using the generalized coordinate system as

$$
\ddot{q}_{i}(t)+2 \zeta \omega_{n i} \dot{q}(t)+\omega_{n i}^{2} q_{i}(t)=f_{i}(t)
$$

Numerical simulations of (5) can be performed at various cutting conditions to obtain the time-domain plots showing tool-tip responses. The time-domain plot helps for chatter identification, and thereby, one can adopt the vibration control technique to suppress the vibrations in the boring bar. Similarly, with the equivalent properties of the CLD boring bar, timedomain analysis are performed.

\subsection{Finite element modelling}

The cantilevered cutting tool is taken into account to study the dynamic behaviour using Euler-Bernoulli beam element, and the natural frequency is determined. Further, the time-domain model is established and simulated to investigate vibrations in the boring bar. The cutting tool is 
discretized into five nodded Euler-Bernoulli beam elements with four degrees of freedom at each node which are considered and shown in Figure 3.

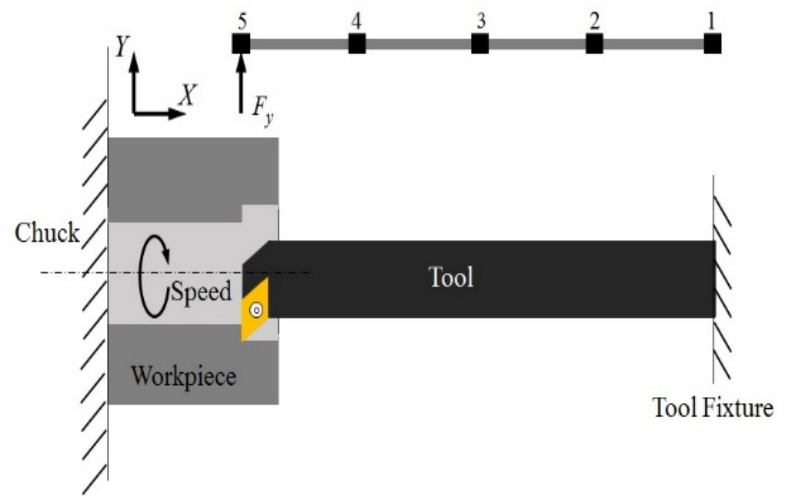

Figure 3. Finite element model of the boring bar [37]

The classical model of cutting force for machining in the radial direction is given by Tobias [38] as

$$
F_{y}=K_{c} d[y(t)-y(t-T)]
$$

where, $K_{c}$ and $d$ represent the cutting force coefficient and depth of cut, respectively. $y(t)$ and $y(t-T)$ are the present and previous displacements of the tool, respectively.

The governing equation of the boring bar in radial direction is given by

$$
[M]\{\ddot{q}\}+[C]\{\dot{q}\}+[K]\{q\}=\left\{F_{y}\right\}
$$

where, $[M]$ is $2 n \times 2 n$ global mass matrix and $[K]$ is $2 n \times 2 n$ global stiffness matrix obtained by accumulating the elemental matrices and the boundary conditions of the tool, (that is, clamped-free) are applied; $n$ is number of elements considered along the boring bar length; $y_{1}$ and $\theta_{1}$ are the displacement and slope, respectively, which are equal to zero at node 1 since the boundary condition is clamped. Moreover, the dynamic cutting force $\left(F_{y}\right)$ is set to the $(n+1)^{t h}$ node of the force matrix and $[C]$ is the damping matrix, which can be estimated from equation given by

$$
[C]=[\phi][M]\left[\operatorname{diag}\left(2 \zeta_{i} \omega_{n i}\right][M][\phi]^{T}\right.
$$

where, $[\phi]$ is a normalized modal matrix that satisfies the conditions such as $[\phi]^{T}[K][\phi]=\left[\operatorname{diag}\left(\omega_{n i}{ }^{2}\right)\right]$ and $[\phi]^{T}[M][\phi]=[I] . \omega_{n i}$ denotes the natural frequency of $i^{\text {th }}$ mode of the internal turning system.

Both $[\phi]$ and $\omega_{i}$ are evaluated by solving the Eigen function characteristic equation of the system, that is, $\left([K]-[\phi] \omega_{i}^{2}\right)\left\{\phi_{i}\right\}=[0]$, where $\left\{\phi_{i}\right\}$ is $i^{t h}$ mode shape vector. $\zeta_{i}$ denotes the damping ratio of the system for $i^{\text {th }}$ mode and obtained from experimental modal analysis
(EMA). EMA is also conducted to validate the natural frequency obtained from finite element model. The impact hammer test setup as shown in Figure 4 is used to determine the modal parameters of the boring bar.

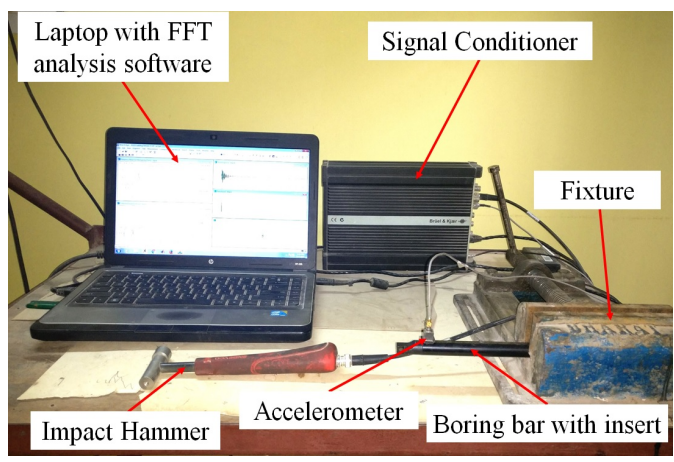

Figure 4. Setup of the impact hammer test

\subsection{Modelling of CLD boring bar}

The use of viscoelastic materials called attention among researchers to suppress the vibrations in the structures because of their high damping performance. However, they cannot be used directly as a structural material due to their low modulus of elasticity [39]. A constrained layer damping (CLD) boring bar (as shown in Figure 4) with three layers such as base material, damping material and a constrained layer is adopted to study the stability of internal turning. The materials of the base layer, damping layer, and constrained layer are selected as $40 \mathrm{cr}$ steel, hybrid composite (carbon/SiC-epoxy), and 317 stainless steel, respectively. The damping layer's primary role is to improve the natural frequency by reducing the boring bar's density and improving the damping capacity. The constrained layer's function is to enhance the boring bar's natural frequency and stiffness and protect the damping layer. The thickness of the damping and constrained layers are taken as $2 \mathrm{~mm}$ and 1 $\mathrm{mm}$ respectively. The diameter of the base material used for the analysis is $20 \mathrm{~mm}$.

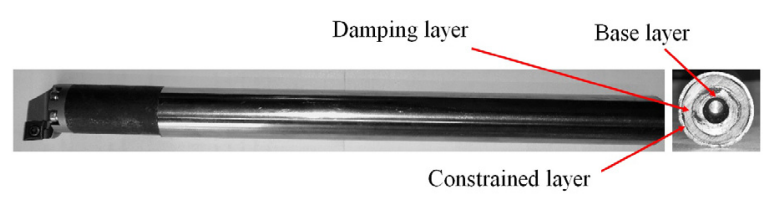

Figure 5. Boring bar with passive CLD treatment

The general methods such as the direct frequency response, complex eigenvalue and modal strain energy (MSE) approaches are popularly used to analyse the dynamic behaviour of composite structures [40]. The first two approaches compute the parameters in the complex domain. The cost of the application of these methods in a complex structure is very high. Thus, in the present study, MSE is employed for the purpose of analysis and optimization of damping parameters in the finite element approach.

The strain energy of a structure can be expressed as

$$
U_{i}=\frac{1}{2}\{\psi\}^{T}[K]_{i}\{\psi\}
$$

where, $i=b, d, c$ and $e$ represent the base material, damping layer, constrained layer and composite boring 
bar, respectively. $\{\psi\}$ denotes a real vector of undamped system. The stiffness matrix is denoted by $[K]_{i}$ here $i=b, d, c$ are for the base layer, damping layer, and the constrained layer, respectively.

The equivalent stiffness matrix $[K]_{e}$ of the CLD boring bar can be evaluated from individual stiffness matrices as

$$
[K]_{e}=[K]_{b}+[K]_{d}+[K]_{c}
$$

The energy dissipated by damping material layer in a cycle is given by

$$
W_{c}=\frac{1}{2} \gamma\{\psi\}^{T}[K]_{d}\{\psi\}
$$

where, $\gamma$ represents the damping material loss factor. The loss factor of CLD composite boring bar is expressed as

$$
\eta=\frac{W_{c}}{U_{e}}=\frac{\gamma[U]_{d}}{[U]_{b}+[U]_{d}+[U]_{c}}
$$

The equivalent bending stiffness and area density of CLD boring bar are determined from the individual material properties as defined by

$$
\begin{aligned}
& {[\rho S]_{e}=[\rho S]_{b}+[\rho S]_{d}+[\rho S]_{c}} \\
& {[E I]_{e}=[E I]_{b}+[E I]_{d}+[E I]_{c}}
\end{aligned}
$$

In order to determine the modal parameters, finite element analysis is carried out using the equivalent material properties, stiffness and mass matrices of the CLD boring bar. Further, time-domain plots such as tool-tip responses with respect to time are numerically simulated using MATLAB program from the evaluated data.

\section{EXPERIMETNAL SETUP AND PROCEDURE}

The experimental setup as shown in Figure 6, comprised a centre lathe (Pinacho; model: ROCIO 180X750), boring bar (TaeguTec; model: HE-D25-SCLCR 09) having length and diameter of $300 \mathrm{~mm}$ and $25 \mathrm{~mm}$, respectively, with carbide insert (CCMT-09T308-MU-TN2000), charge amplifier (IPA Pvt Ltd., model: CA201A0), accelerometer (Bruel \& Kjaer, model: 4332) of sensitivity $63.5 \mathrm{mV} / \mathrm{g}$, and the digital phosphor oscilloscope (Tektronix; model: DPO4034). The cutting experiments are carried out on pre-drilled $100 \mathrm{~mm}$ long workpieces (1020 steel) with an inner and outer diameter of $40 \mathrm{~mm}$ and $50 \mathrm{~mm}$, respectively, without cutting fluid. During each cutting test, a new cutting insert is used.

Initially, a boring tool with cutting insert is mounted on the tool post for a fixed overhang, and a pre-drilled workpiece is held in the lathe chuck. A piezoelectric accelerometer is then attached to the toolholder in the radial cutting direction for measuring regenerative vibrations. Vibration signals acquired from the accelerometer are fed to the oscilloscope through a signal conditioner to record the amplitude data. This vibration displacements are plotted to compare the performance of the conventional and CLD boring bar.

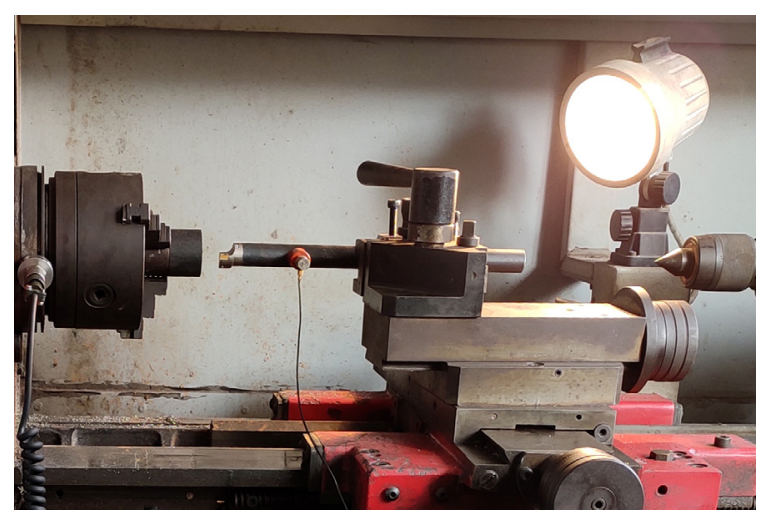

Figure 6. Experimental setup

\section{RESULTS AND DISCUSSIONS}

Initially, the fundamental frequency of the conventional as well as the sandwiched tool are obtained as $(374 \mathrm{~Hz}$, $480 \mathrm{~Hz})$ and $(373 \mathrm{~Hz}, 478 \mathrm{~Hz})$, respectively, from EBT and FEM methods. Further, experimental modal analysis (EMA) is conducted on both the traditional and CLD boring tools to estimate their modal parameters such as natural frequency and damping ratio using impact hammer test setup and obtained the frequency response function (FRF), as shown in Figure 7.

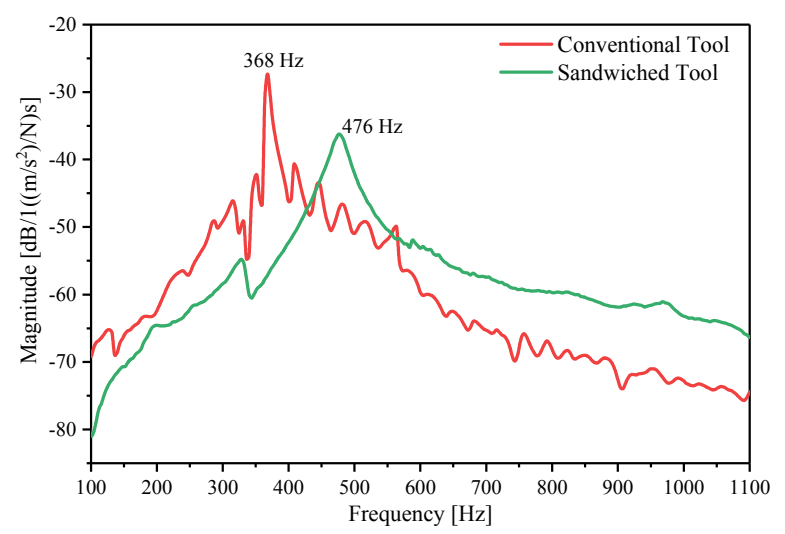

Figure 7. Frequency response plot for conventional and CLD boring bar [37]

The fundamental mode of the conventional and CLD or sandwiched boring tool are found as $368 \mathrm{~Hz}$ and 476, $\mathrm{Hz}$ respectively. Also, the damping ratios of conventional and sandwiched tool are estimated as 0.01 and 0.03 , respectively. The results of EBT and FEM are verified with EMA results and found that the results are authentic.

Further, the static stiffness of the conventional and sandwiched tool are evaluated from the FRF at zero frequency, respectively, are $1.3473 \mathrm{MN} / \mathrm{m}$ and 2.9746 $\mathrm{MN} / \mathrm{m}$. Cutting experiments are conducted with a constant cutting speed and depth of cut and different feed rates, and recorded the force signals from the dynamometer to find out the cutting force coefficients. Finally, the slope of the graph plotted between feed rate and cutting force is estimated. The cutting force coefficient is determined by dividing the slope with the depth of cut as $2384 \mathrm{~N} / \mathrm{mm} 2$ and measured the mass of conventional and CLD boring bars as $0.252 \mathrm{~kg}$ and 0.4 $\mathrm{kg}$, respectively. Further, the semi-analytical stability lobe diagram (SLD) is constructed using modal para- 
meters, shown in Figure 8. From the graph, different cutting conditions are chosen to conduct cutting experiments, which include different cutting zones such as stable, marginally stable and chatter.

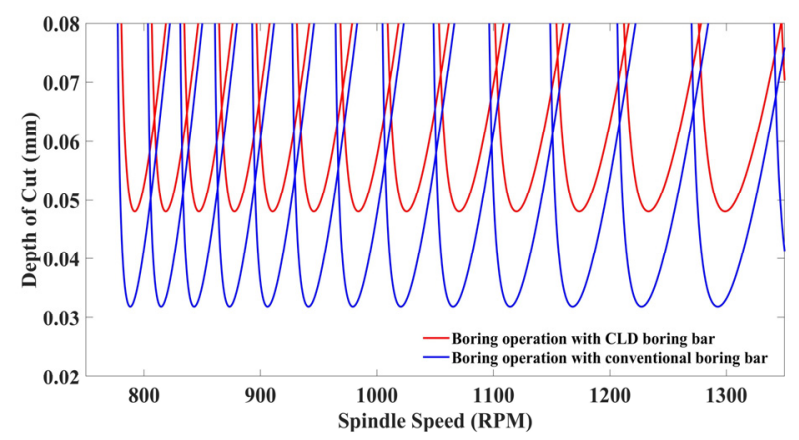

Figure 8. Stability lobe plots for conventional and CLD boring bars

\subsection{Results of the beam theory}

In order to study the effectiveness of the CLD boring bar over the conventional boring bar, various cutting speeds such as $900 \mathrm{rpm}, 100 \mathrm{rpm}$ and $1200 \mathrm{rpm}$, constant depth of cut $0.05 \mathrm{~mm}$ and a feed of 0.02 $\mathrm{mm} / \mathrm{rev}$ are considered.

It is clear from Figure 8 that cutting condition of 900 rpm speed and $0.05 \mathrm{~mm}$ depth of cut is unstable and slightly stable for internal turning with the conventional boring bar and slightly stable for the CLD boring bar, respectively. For this condition, the tool-tip displacements of both conventional and CLD boring bar shown in Figure 9 are obtained using MATLAB DDE23 solver.

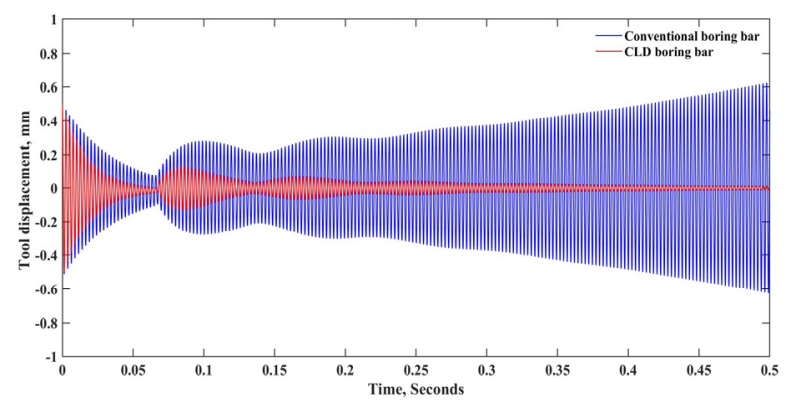

Figure 9. Tool-tip displacements of the conventional and CLD boring bar at a speed of $900 \mathrm{rpm}$ and $0.05 \mathrm{~mm}$ depth of cut

From Figure 9, it is observed that the tool-tip response is divergent in nature for the conventional boring bar which means the machining process is unstable and develops chatter marks on the machined surface, whereas the tool-tip displacements are decaying gradually, which means the cutting process is stable. It is obvious that the tool-tip response of the conventional and CLD boring bar is satisfying the cutting condition taken from the stability diagram, which shows the authenticity. Moreover, it is also observed that the CLD performs better compared to the conventional boring bar at the same cutting condition due to the dissipation of higher energy and improved stiffness of CLD boring bar.

Further, a cutting condition indicating the cutting speed of $1200 \mathrm{rpm}$ and the depth of cut of 0.05 is considered from the SLD. It is evident from SLD that both conventional and CLD boring bar exhibit stable conditions. However, the CLD boring bar is critically stable, which means the tool displacement of the CLD boring bar minimized effectively compared to the conventional boring bar. Figure 10 shows the tool-tip response of conventional and CLD boring bars, respecttively, are stable and critically stable. The cutting condition taken from the SLD is valid. This means that the stability diagram is valid for the above intermittent cutting conditions.

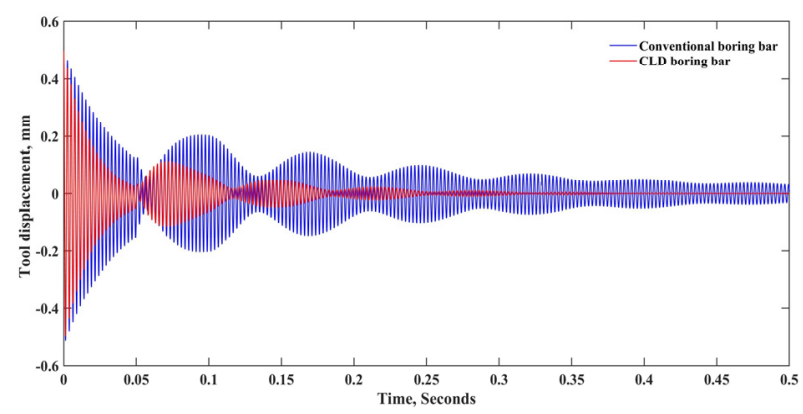

Figure 10. Tool-tip displacements of the conventional and CLD boring bar at a speed of $1200 \mathrm{rpm}$ and $0.05 \mathrm{~mm}$ depth of cut

It can be concluded from the simulations that the vibrations that occur during the boring process in the tool can be attenuated by improving the system's natural frequency, damping capacity and stiffness.

\subsection{Results of the finite element modelling}

The results attained from the finite element modelling of the tool are detailed in this section. Initially, global mass and stiffness matrices are constructed using modal parameters of EMA. A convergence analysis is further performed to determine the predominant natural frequency of the conventional and CLD boring bar for the first mode of vibration.
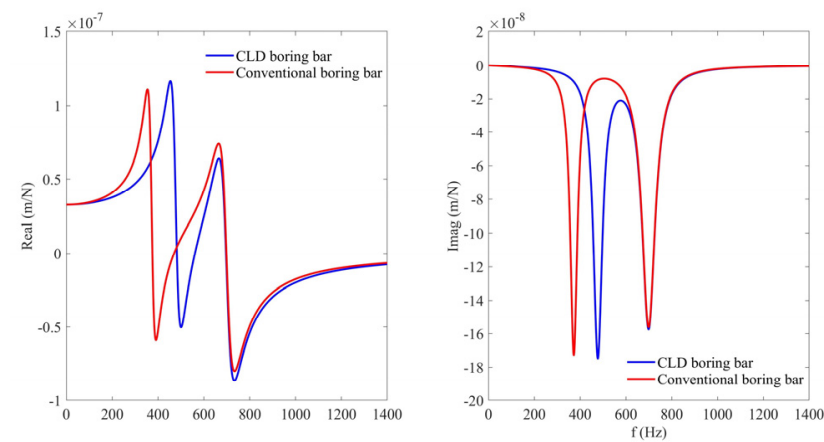

Figure 11. The real and imaginary parts of FRF for conventional and CLD boring bars

The natural frequencies are approximated by considering the free vibration in (7) and making force term equal to zero. Figure 11 shows the real and imaginary parts of FRF, which evaluates the modal parameters. First, an assumed FRF with undetermined natural frequency and damping ratio is used and least squares method is then adopted for extracting the modal parameters using MATLAB code. The damping ratios are also determined from EMA and damping matrix $[C]$ is developed with the use of (8). Moreover, the equivalent material properties of the CLD boring bar are 
estimated from the properties of individual material. Further, time-domain plots are numerically simulated to study the tool-tip responses using MATLAB from the governing equation given in (7). The time-domain plots define the limiting depth of cut in internal turning for all speed values, resulting in stability lobe diagram. Timedomain simulations are time taking process, whereas finding stability lobes is easier in the frequency domain. However, the time-domain simulations are still useful compared to stability lobes plotted in the frequency domain as monitoring of cutting tool is more convenient in the time-domain. The time domain plots obtained from the FEM for both conventional as well as the CLD tool are shown in Figure 12. The cutting speed and depth of cut used for the simulation are $1000 \mathrm{rpm}$ and $0.05 \mathrm{~mm}$ respectively. The simulation is performed using the delay differential equations using MATLAB.

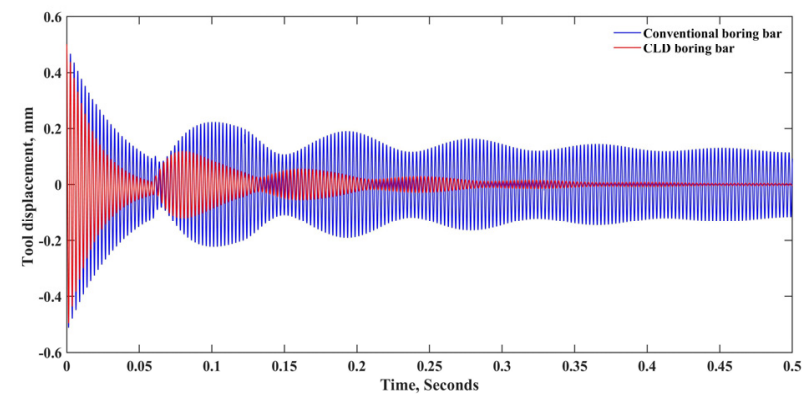

Figure 12. Tool tip displacements vs time plot for both the conventional and CLD boring tool using FEM

From Figure 12, it has been observed that the time domain obtained for the conventional boring tool from FEM shows a constant vibration level, which indicates a critically stable state of the machining process for a given set of cutting conditions. It is also found that the time domain of the CLD boring tool shows that vibration decay results in a stable cutting process for a set of parameters. This is due to the damping layer introduced in the CLD boring bar that has the high damping capacity, which can dissipate the vibration energy produced in the tool within the volume of the material. Therefore, the vibrations can be controlled with the provision of damping materials. The CLD boring bar changes the dynamic stiffness over the constrained layer and improves the damping performance throughout damping layer. Hence, it is concluded that the results of beam theory are very useful to study the FEM results. It is found that the CLD boring bar shows better results compared to the conventional tool. Thus, the vibrations in the tool are controlled with use of the CLD boring tool. It is suggested that the change of damping material in the CLD tool may improve the tool stiffness as well as damping capacity and results in reduced vibrations.

\subsection{Experimental results}

Cutting experiments are performed at a speed and depth of cut of $900 \mathrm{rpm}$ and $0.05 \mathrm{~mm}$, respectively, to validate the numerical results and to measure the performance of the CLD boring bar over the conventional boring bar. Time-domain, plots as shown in Figure 13 are obtained from cutting experiments. It is observed that the cutting operation with the conventional boring bar results in sever chatter at this cutting condition. Whereas stable cutting is observed with the CLD boring bar. The use of the CLD boring bar in the intermittent cutting zones results in better results and minimizes the chatter in internal turning. Moreover, the surfaces of machined components are given in Figure 14.

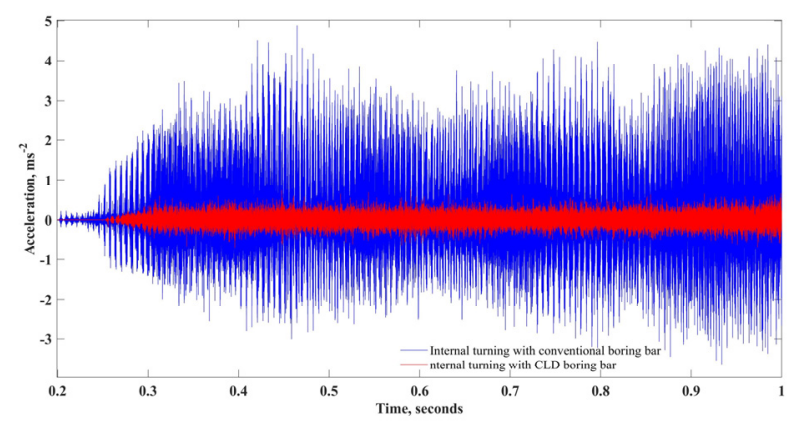

Figure 13. The tool-tip response of the conventional and CLD boring tool obtained from experiments

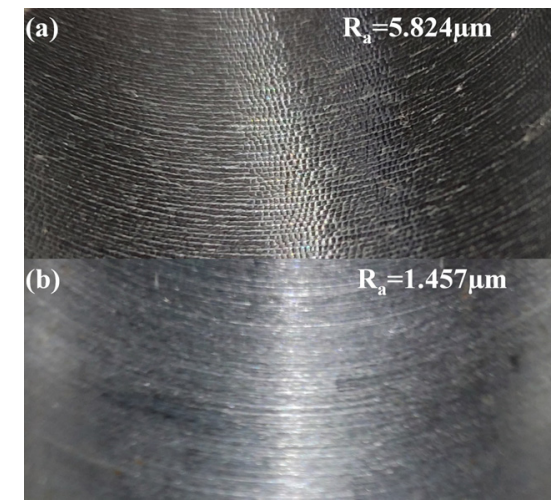

Figure 14. The surface of the machined component in internal turning with (a) the conventional and (b) CLD boring tool

The surface roughness values of machined component with conventional and CLD boring bars are 5.824 $\mu \mathrm{m}$ and $1.457 \mu \mathrm{m}$ respectively. The surface roughness values of machined part clearly shows that the surface obtained from boring with CLD boring is much better compared to the conventional boring bar.

\section{CONCLUSIONS}

The stability of internal turning with the conventional and CLD boring bar are investigated using EulerBernoulli theory (EBT) and beam and finite element modelling (FEM). The designed boring bar consists of a cutting head, base layer, damping layer and constrained layer, which can significantly enhance the dynamic performance of the internal turning process. In the meantime, the efficiency and capability of the CLD boring bar for suppressing forced vibration and vibration due to chatter are presented based on numerical and experimental approaches. The vibration suppression mechanism is also investigated. The results show that:

- The natural frequencies obtained from EBT, FEM are validated by performing EMA using impact hammer test, and are in good agreement among them.

- The time-domain or tool-tip responses obtained from numerical simulations are well coincident 
with the cutting states taken from SLDs. The results of numerical simulations are validated with the cutting experiments. From all these analyses, it is concluded that the use of the CLD boring bar drastically reduces the tool vibrations compared with a conventional one. The CLD boring tool's performance is further improved by adopting other high damping materials as the damping layer.

- The method used to minimize the forced vibration is different from the method used for the suppression of chatter. The forced vibrations can be entirely prevented by shifting the boring bar's natural frequency, for instance, changing the dynamic stiffness of the CLD boring bar. On the other hand, the chatter vibration cannot be completely eliminated due to its complexity at low cutting velocity zones. It can only be controlled by improving the damping in the CLD boring bar.

- The CLD boring bar can modify its dynamic stiffness throughout the constrained layer and improves the performance of damping through damping layer. Therefore, with the use of the CLD boring bar the forced vibration can be avoided completely and chatter can be reduced to some extent. The ability to suppress chatter with the CLD boring bar is improved five times compared to the standard boring bar in the given cutting zones.

The design concept of CLD can be further extended to other machining operations to suppress the vibration. Moreover, an active control can be also implemented with the PVDF sensor over the surface of the CLD boring bar.

\section{APPENDIX}

FEM is performed for both the conventional and CLD boring bars with an overhang length of $300 \mathrm{~mm}$ and a diameter of $25 \mathrm{~mm}$. The thickness of the damping and constrained layers are taken as $2 \mathrm{~mm}$ and $1 \mathrm{~mm}$, respectively. The results obtained from the conventional and CLD boring bar are discussed in the previous section. The effective mass and effective stiffness matrices obtained from the FEM are given at the end of paper.

\section{CONFLICT OF INTEREST}

It is to clearly state that there is no conflict of interest with any organizations or people to disclose that could inappropriately affect the manuscript content.

\section{FUNDING}

None of the authors listed in the manuscript has financial support or any personal association with organizations and people or that could inappropriately affect the manuscript content.

\section{REFERENCES}

[1] Stone, B.: Chatter and machine tools, Springer, New York, 2014.

[2] Karabegović, I., Novkinić, B., Husak, E.: Experimental identification of tool holder acceleration in the process of longitudinal turning, FME Transactions, Vol. 43, No. 2, pp. 131-137, 2015.

[3] Deepanraj, B., Raman, L.A., Senthilkumar, N. and Shivasankar, J.: Investigation and optimization of machining parameters influence on surface roughness in turning AISI 4340 steel, FME Transactions, Vol. 48, No. 2, pp. 383-390, 2020.

[4] Nam, S., Hayasaka, T., Jung, H. and Shamoto, E.: Proposal of novel chatter stability indices of spindle speed variation based on its chatter growth characteristics, Precision Engineering, Vol. 62, pp. 121-133, 2020.

[5] Kakinuma, Y., Enomoto, K., Hirano, T. and Ohnishi, K.: Active chatter suppression in turning by band-limited force control, CIRP Annals, Vol. 63, No. 1, pp. 365-368, 2014.

[6] Bansal, A. and Law, M.: A Receptance Coupling Approach to Optimally Tune and Place Absorbers on Boring Bars for Chatter Suppression, Procedia CIRP, Vol. 77, pp. 167-170, 2018.

[7] Guo, Y., Dong, H., Wang, G. and Ke, Y.: Vibration analysis and suppression in robotic boring process, International Journal of Machine Tools and Manufacture, Vol. 101, pp. 102-110, 2016.

[8] Venter, G. S., do Paraizo Silva, L. M., Carneiro, M. B., da Silva, M. M.: Passive and active strategies using embedded piezoelectric layers to improve the stability limit in turning/boring operations, The International Journal of Advanced Manufacturing Technology, Vol. 89, No. 9-12, pp. 2789-2801, 2017.

[9] Yigit, U., Cigeroglu, E., and Budak, E.: Chatter reduction in boring process by using piezoelectric shunt damping with experimental verification, Mechanical Systems and Signal Processing, Vol. 94, pp. 312-321, 2017.

[10] Tang, B., Akbari, H., Pouya, M., Pashaki, P. V.: Application of piezoelectric patches for chatter suppression in machining processes, Measurement, Vol. 138, pp. 225-231, 2019.

[11] Mei, D., Kong, T., Shih, A. J., and Chen, Z.: Magnetorheological fluid-controlled boring bar for chatter suppression, Journal of materials processing technology, Vol. 209, No. 4, pp. 1861-1870, 2009.

[12] Pour, D. S., Behbahani, S.: Semi-active fuzzy control of machine tool chatter vibration using smart MR dampers, The International Journal of Advanced Manufacturing Technology, Vol. 83, No. 1-4, pp. 421-428, 2016.

[13]Biju, C. V., Shunmugam, M. S.: Performance of magnetorheological fluid based tunable frequency boring bar in chatter control, Measurement, Vol. 140, pp. 407-415, 2019.

[14]Fallah, M., and Moetakef Imani, B.: Analytical prediction of stability lobes for passively damped boring bars, Journal of Mechanics, Vol. 33, No. 5, pp. 641-654, 2017.

[15]Liu, X., Liu, Q., Wu, S., Liu, L., and Gao, H.: Research on the performance of damping boring bar with a variable stiffness dynamic vibration 
absorber, The International Journal of Advanced Manufacturing Technology, Vol. 89, No. 9-12, pp. 2893-2906, 2017.

[16]Liu, X., Liu, Q., Wu, S., Li, R., and Gao, H.: Analysis of the vibration characteristics and adjustment method of boring bar with a variable stiffness vibration absorber, The International Journal of Advanced Manufacturing Technology, Vol. 98, No. 1-4, pp. 95-105, 2018.

[17] Thomas, M. D., W. A. Knight, and M. M. Sadek.: The impact damper as a method of improving cantilever boring bars, Journal of Engineering for Industry, Vol. 97, No. 3, pp. 859-866, 1975.

[18] Edhi, E., Hoshi, T.: Stabilization of high frequency chatter vibration in fine boring by friction damper, Precision engineering, Vol. 25, No. 3, pp. 224-234, 2001.

[19] Biju, C. V., and Shunmugam, M. S.: Investigation into effect of particle impact damping (PID) on surface topography in boring operation, The International Journal of Advanced Manufacturing Technology, Vol. 75, No. 5-8, pp. 1219-1231, 2014.

[20]Chockalingam, S., Natarajan, U., and George Cyril, A.: Damping investigation in boring bar using hybrid copper-zinc particles, Journal of Vibration and Control, Vol. 23, No. 13, pp. 2128-2134, 2017.

[21] Diniz, A. E., da Silva, W. T. A., Suyama, D. I., Pederiva, R., and Albuquerque, M. V.: Evaluating the use of a new type of impact damper for internal turning tool bar in deep holes, The International Journal of Advanced Manufacturing Technology, Vol. 101, No. 5-8, pp. 1375-1390, 2019.

[22] Lee, D. G., Suh, N. P.: Manufacturing and testing of chatter free boring bars, CIRP Annals, Vol. 37, No. 1, pp. 365-368, 1988.

[23] Nagano, S., Koizumi, T., Fujii, T., Tsujiuchi, N., Ueda, H., and Steel, K.: Development of a composite boring bar. Composite structures, Vol. 38, No. 1-4, pp. 531-539, 1997.

[24] Rivin, E. I., Kang, H. L., and Kops, L.: Improving dynamic performance of cantilever boring bars, CIRP Annals, Vol. 38, No. 1, pp. 377-380, 1989.

[25] Hwang, H. Y., Kim, J. K.: Design and manufacture of a carbon fiber epoxy rotating boring bar, Composite Structures, Vol. 60, No. 1, pp.115-124, 2003.

[26] Suzuki, N., Nishimura, K., Watanabe, R., Kato, T., and Shamoto, E.: Development of novel anisotropic boring tool for chatter suppression. Procedia CIRP, Vol. 1, pp. 56-59, 2012.

[27] Ghorbani, S., Rogov, V. A., Carluccio, A., and Belov, P. S.: The effect of composite boring bars on vibration in machining process. The International Journal of Advanced Manufacturing Technology, Vol. 105, No. 1-4, pp. 1157-1174, 2019.

[28] Fu, Q., Lundin, D., Nicolescu, C. M.: Anti-vibration engineering in internal turning using a carbon nanocomposite damping coating produced by PECVD process, Journal of materials engineering and performance, Vol. 23, No. 2, pp. 506-517, 2014.
[29]Ross D, Ungar E.E., Kerwin E.M.: Damping of plate flexural vibrations by means of viscoelastic laminate. ASME Annual Meeting: pp. 48-87, 1959.

[30] Garinis, D., Dinulović, M. and Rašuo, B.: Dynamic analysis of modified composite helicopter blade. FME Transactions, Vol. 40, No. 2, pp. 63-68, 2012.

[31]Rao, S.A., Jusoh, M.A., Hamid, M.K.A. and Zakaria, K.: Reduction of Disc Brake Squeal Noise Using Constrained Layer Dampers, Jurnal Teknologi, Vol. 79, No. 7-4, pp. 83-87| 2017.

[32]De, S.M.C., Rivera, Z.B. and Guida, D.: Finite element analysis on squeal-noise in railway applications. FME Transactions, Vol. 46, No. 1, pp. 93-100, 2018.

[33]Xia, F., Liu, Z.Q., Song, Q.H.: Boring bar with constrained damping. Acta Aeronautica et Astronautica Sinica, Vol. 35, No. 9, pp. 252-2659, 2014.

[34] Yuhuan, Z., Yongsheng, R., Jishuang, T., Jingmin, M.: Chatter stability of the constrained layer damping composite boring bar in cutting process, Journal of Vibration and Control, Vol. 25, No. 16, pp. 2204-2214, 2019.

[35] Bonda, A.G.Y., Nanda, B.K. and Jonnalagadda, S.: Vibration signature based stability studies in internal turning with a wavelet denoising preprocessor, Measurement, Vol. 154, pp. 107520, 2020.

[36] Sadredine, A., Nouredine, O. and Cherif, D.M.: Modeling and experimental validation of dynamic response of the cutting tool in turning operations, FME Transactions, Vol 48, No, 2, pp. 454-459, 2020.

[37] Yuvaraju, B.A.G., Nanda, B.K. and Srinivas, J.: Analytical and Finite Element Modelling of the Boring bar for Stability Studies, in International Conference on Recent Developments in Mechanical Engineering (ICRDME-2019), pp. 1-10, 2019.

[38] Tobias, S.A.: Machine-tool vibration, J. Wiley, 1965.

[39] Song, Q., Shi, J., Liu, Z., Wan, Y. and Xia, F.: Boring bar with constrained layer damper for improving process stability, The International Journal of Advanced Manufacturing Technology, Vol. 83, No. 9-12, pp.1951-1966, 2016.

[40] Xu, Y., Gao, W., Yu, Y., Zhang, D., Zhao, X., Tian, Y. and Cun, H.: Dynamic optimization of constrained layer damping structure for the headstock of machine tools with modal strain energy method, Shock and Vibration, Vol. 2017, pp. $1-13,2017$

\section{NOMENCLATURE}

$\begin{array}{ll}E & \text { Modulus of elasticity of tool } \\ A & \text { Area of cross section of tool } \\ c & \text { Damping ceofficient } \\ \rho & \text { Material density of cutting tool } \\ f(x, t) & \text { Distributed force acting on the boring bar } \\ K_{c} & \text { Cutting force coefficeint } \\ d & \text { Width of cut }\end{array}$




\begin{tabular}{|c|c|}
\hline$y(x, t)$ & Cureent displacment of the tool \\
\hline$y(x, t-T)$ & Previous dsiplacement of the tool \\
\hline$\chi_{i}(x)$ & Mode or Characteristic function \\
\hline$q_{i}(t)$ & Displacement of the tool \\
\hline$\zeta_{i}$ & Daming ratio for ith mode \\
\hline$\omega_{n i}$ & Natural frequency for ith mode \\
\hline$f_{i}(t)$ & Cutting tool force \\
\hline$[M]$ & Mass Matrix \\
\hline$[C]$ & Damping Matrix \\
\hline$[K]$ & Stiffness Matrix \\
\hline$\{q\}$ & Displacement matrix \\
\hline$F_{y}$ & Force acting at the tip of tool \\
\hline$[\phi]$ & Normalized modal matrix \\
\hline$[I]$ & Identity matrix \\
\hline$U_{b}$ & Strain energy of base material \\
\hline$U_{d}$ & Strain energy of damping layer \\
\hline$U_{c}$ & Strain energy of constrained layer \\
\hline$U_{e}$ & Strain energy of composite \\
\hline$[K]_{b}$ & Base layer stiffness matrix \\
\hline$[K]_{d}$ & Damping layer stiffness matrix \\
\hline$[K]_{C}$ & Consrined layer stiffness matrix \\
\hline$[K]_{e}$ & Equivalent stiffness matrix \\
\hline$\{\psi\}$ & Real vector of undamped system \\
\hline$W_{c}$ & $\begin{array}{l}\text { Dissipation of energy by the damping layer } \\
\text { in cycle }\end{array}$ \\
\hline$\gamma$ & Loss factor of damping material \\
\hline$\eta$ & Loss factor of CLD composite boring bar \\
\hline$[\rho S]_{b}$ & Area density of base layer \\
\hline$[\rho S]_{d}$ & Area density of damping layer \\
\hline$[\rho S]_{c}$ & Area density of constrained layer \\
\hline$[\rho S]_{e}$ & Equivalent area density of CLD boring bar \\
\hline$[E I]_{b}$ & Bending stiffness of base layer \\
\hline
\end{tabular}

$\begin{array}{ll}{[E I]_{d}} & \text { Bending stiffness of damping layer } \\ {[E I]_{C}} & \text { Bending stiffness of constrained layer } \\ {[E I]_{e}} & \text { Equivalent bending stiffness of CLD boring } \\ \end{array}$

\section{ИСТРАЖИВАЊЕ СТАБИЛНОСТИ КОД УНУТРАШЫЕ ОБРАДЕ СТРУГАњЕМ ПОМОһУ ВРЕТЕНА БУШИЛИЦЕ СА ПАСИВНИМ ПРИГУШИВАЊЕМ ОГРАНИЧАВАЈУЋИМ СЛОЈЕМ}

\section{Б.А.Г. Јувараџу, Б.К. Нанда, Ј. Шринивас}

Вибрације које настају код вретена бушилице приликом обраде стругањем погоршавају квалитет обрађене површине и скраћују век трајања алата, што доводи до стварања велике буке у току процеса обраде. Стога је потребно елиминисати нежељене вибрације побољшањем динамичке крутости вретена бушилице и капацитетом пригушивања. Рад истражује пасивно пригушивање ограничавајућим слојем вретена бушилице са хибридним пригушним слојем у циљу изучавања стабилности система унутрашње обраде стругањем. Најпре је проучен конвенционални алат као и алат са пригушним слојем помоћу Ојлер-Бернулијеве теорије греде док је евалуација обављена ФЕМ моделирањем. Функције фреквентног одговора добијене испитивањем ударом чекића коришћене су за процену модалних параматера. Помоћу модалних параметара израђени су режњеви дијаграма полуаналитичке стабилности система бушења конвенционалним и алатом са пригушним слојем. Одзиви врха алата за различите услове резања су нумерички симулирани да би се проценила и проучила стабилност. Експерименти са обе врсте алата су изведени у циљу анализе стабилности и поређења одзива врха алата са нумеричким резултатима. Утврђено је да постоји слагање нумеричких и експерименталних резултата за изабране услове резања. Такође је утврђено да бушилица са хибридним пригушним слојем смањује померање вибрација за пет пута у односу на конвенционални алат.

\section{Effective stiffness and effective mass matrices for conventional boring bar}

$$
[K]_{e}=10^{6} \times\left[\begin{array}{cccccccccc}
100.80 & 3.78 & -100.80 & 3.78 & 0 & 0 & 0 & 0 & 0 & 0 \\
3.78 & 0.19 & -3.78 & 0.09 & 0 & 0 & 0 & 0 & 0 & 0 \\
-100.80 & -3.78 & 201.61 & 0 & -100.80 & 3.78 & 0 & 0 & 0 & 0 \\
3.78 & 0.09 & 0 & 0.38 & -3.78 & 0.09 & 0 & 0 & 0 & 0 \\
0 & 0 & -100.80 & -3.78 & 201.61 & 0 & -100.80 & 3.78 & 0 & 0 \\
0 & 0 & 3.78 & 0.09 & 0 & 0.38 & -3.78 & 0.09 & 0 & 0 \\
0 & 0 & 0 & 0 & -100.80 & -3.78 & 201.61 & 0 & -100.80 & 3.78 \\
0 & 0 & 0 & 0 & 3.78 & 0.09 & 0 & 0.38 & -3.78 & 0.09 \\
0 & 0 & 0 & 0 & 0 & 0 & -100.80 & -3.78 & 100.80 & -3.78 \\
0 & 0 & 0 & 0 & 0 & 0 & 3.78 & 0.09 & -3.78 & 0.19
\end{array}\right]
$$




$[M]_{e}=10^{-6} \rtimes\left[\begin{array}{cccccccccc}106659.88 & 1128.13 & 36920.73 & -666.62 & 0 & 0 & 0 & 0 & 0 & 0 \\ 1128.13 & 15.38 & 666.62 & -11.54 & 0 & 0 & 0 & 0 & 0 & 0 \\ 36920.73 & 666.62 & 213319.75 & 0 & 36920.73 & -666.62 & 0 & 0 & 0 & 0 \\ -666.62 & -11.54 & 0 & 30.77 & 666.62 & -11.54 & 0 & 0 & 0 & 0 \\ 0 & 0 & 36920.73 & 666.62 & 213319.75 & 0 & 36920.73 & -666.62 & 0 & 0 \\ 0 & 0 & -666.62 & -11.54 & 0 & 30.77 & 666.62 & -11.54 & 0 & 0 \\ 0 & 0 & 0 & 0 & 36920.73 & 666.62 & 213319.75 & 0 & 36920.73 & -666.62 \\ 0 & 0 & 0 & 0 & -666.62 & -11.54 & 0 & 30.77 & 666.62 & -11.54 \\ 0 & 0 & 0 & 0 & 0 & 0 & 36920.73 & 666.62 & 106659.88 & -1128.13 \\ 0 & 0 & 0 & 0 & 0 & 0 & -666.62 & -11.54 & -1128.13 & 15.38\end{array}\right]$

Effective stiffness and effective mass matrices for CLD boring bar

$[K]_{e}=10^{6} \times\left[\begin{array}{cccccccccc}119.99 & 4.50 & -119.99 & 4.50 & 0 & 0 & 0 & 0 & 0 & 0 \\ 4.50 & 0.22 & -4.50 & 0.11 & 0 & 0 & 0 & 0 & 0 & 0 \\ -119.99 & -4.50 & 239.98 & 0 & -119.99 & 4.50 & 0 & 0 & 0 & 0 \\ 4.50 & 0.11 & 0 & 0.45 & -4.50 & 0.11 & 0 & 0 & 0 & 0 \\ 0 & 0 & -119.99 & -4.50 & 239.98 & 0 & -119.99 & 4.50 & 0 & 0 \\ 0 & 0 & 4.50 & 0.11 & 0 & 0.45 & -4.50 & 0.11 & 0 & 0 \\ 0 & 0 & 0 & 0 & -119.99 & -4.50 & 239.98 & 0 & -119.99 & 4.50 \\ 0 & 0 & 0 & 0 & 4.50 & 0.11 & 0 & 0.45 & -4.50 & 0.11 \\ 0 & 0 & 0 & 0 & 0 & 0 & -119.99 & -4.50 & 119.99 & -4.50 \\ 0 & 0 & 0 & 0 & 0 & 0 & 4.50 & 0.11 & -4.50 & 0.22\end{array}\right]$

$[M]_{e}=10^{-6} \rtimes\left[\begin{array}{cccccccccc}84264.23 & 891.26 & 29168.39 & -526.65 & 0 & 0 & 0 & 0 & 0 & 0 \\ 891.26 & 12.15 & 526.65 & -9.12 & 0 & 0 & 0 & 0 & 0 & 0 \\ 29168.39 & 526.65 & 168528.47 & 0 & 29168.39 & -526.65 & 0 & 0 & 0 & 0 \\ -526.65 & -9.12 & 0 & 24.31 & 526.65 & -9.12 & 0 & 0 & 0 & 0 \\ 0 & 0 & 29168.39 & 526.65 & 168528.47 & 0 & 29168.39 & -526.65 & 0 & 0 \\ 0 & 0 & -526.65 & -9.12 & 0 & 24.31 & 526.65 & -9.12 & 0 & 0 \\ 0 & 0 & 0 & 0 & 29168.39 & 526.65 & 168528.47 & 0 & 29168.39 & -526.65 \\ 0 & 0 & 0 & 0 & -526.65 & -9.12 & 0 & 24.31 & 526.65 & -9.12 \\ 0 & 0 & 0 & 0 & 0 & 0 & 29168.39 & 526.65 & 84264.23 & -891.26 \\ 0 & 0 & 0 & 0 & 0 & 0 & -526.65 & -9.12 & -891.26 & 12.15\end{array}\right]$

